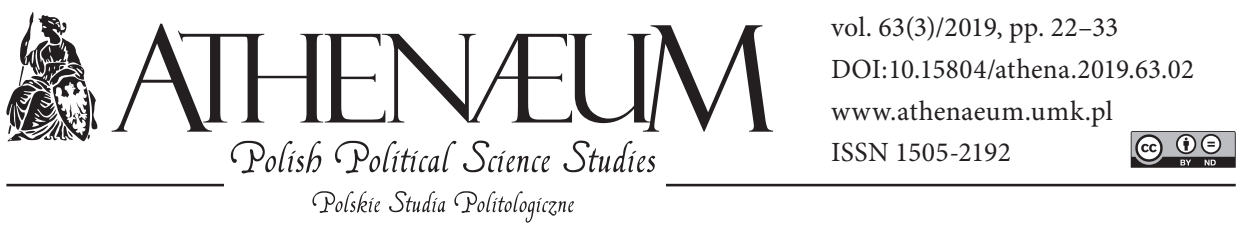

\title{
MINORITY GOVERNMENT AND LEGISLATIVE POLITICS IN POLAND, 1989-2007
}

\author{
RZĄD MNIEJSZOŚCIOWY I POLITYKA LEGISLACYJNA \\ W POLSCE W LATACH 1989-2007
}

Robert Radek* $\odot$

\begin{abstract}
One of the scientifically interesting questions is explaining the functioning and effectiveness of the minority government. An analysis of Polish governments (1989-2007) finds mixed support for the importance of parliamentary procedural mechanisms. Yet an analysis of the Polish government after the collapse of communism reveals that a governing party with a central position in the party system can indeed shift alliances and maintain quite effective governance. Additionally, the evidence indicates that minority governments may also rely on alliances across parliament deputies who want prolong the term of office as long as possible. The article concentrates also on duration and legislative effectiveness of Polish minority cabinets.
\end{abstract}

Keywords: minority government (cabinet); political parties; legislation; effectiveness
Jednym $\mathrm{z}$ interesujących naukowo pytań jest wyjaśnienie funkcjonowania i efektywności rządów mniejszościowych. Analiza polskich rządów w latach 1989-2007 potwierdza wpływ parlamentarnych mechanizmów i procedur w tym względzie. Analiza funkcjonowania polskich gabinetów rządowych po upadku komunizmu pokazuje, że partia rządząca $\mathrm{z}$ centralną pozycją w systemie partyjnym może faktycznie zmienić sojusze i utrzymać całkiem skuteczne rządy. Dodatkowo wiele wskazuje na to, że rządy mniejszościowe mogą również polegać na sojuszach między posłami do parlamentu, którzy chcą jak najdłużej przedłużyć kadencję. Artykuł koncentruje się także na długości funkcjonowania i skuteczności legislacyjnej polskich gabinetów mniejszościowych.

Słowa kluczowe: rząd mniejszościowy; partia polityczna; legislacja; efektywność

* University of Silesia in Katowice, Faculty of Social Sciences. 


\section{INTRODUCTION}

The comparative performance of distinct types of democratic government is at the heart of academic inquiry in political science. At one level, the discipline debates the advantages and disadvantages of parliamentary, presidential, and semi-presidential institutional structures. Within these macro-institutional categories, fundamental distinctions are made between single-party versus coalition governments and majority versus minority governments and their relative impact on government stability, legislative success and effectiveness, policy outcomes, and regime survival (Field, 2014, p. 298).

This article focuses on minority parliamentary government in Poland, which is often deemed to be the most problematic form of parliamentary government. An adequate understanding of the phenomena of minority governments in Poland must consider the fact that it was not an expected solution in the transforming state after the collapse of communism in 1989. As it is known, minority government comprises one or more parties that hold less than an absolute majority of the seats in the legislature. The frequency of minority government in Poland stands out in comparative perspective. Between the first not totally free post-communist elections in 1989 and the November 2007 elections, Poland had ten majority and eight minority governments (44,4 per cent). If we additionally assume the criterion of division between left and right axis, then six of these mentioned cabinets were nominal right-wing offices, which constituted $3 / 4$ of all minority governments. It is also characteristic that the most minority governments (six out of eight) appeared after the adoption of the new Polish constitution in 1997. This is undoubtedly favored by the constitutional structure introduced during the adoption of the new Basic Law, which is the so-called constructive vote of no confidence, which protects the duration of the government not having sufficient political backing in parliament.

After 1989 in Poland there has been established parliamentary-governmental system, where legislative majorities have instruments at their disposal (such as no-confidence votes and investiture votes) and control the composition of the government and government policy. However, it should be stressed that the application of the majority principle to parliamentary responsibility is not altogether straightforward. In Polish parliamentary regime, cabinets must at various junctures produce legislative majorities in order to perform their constitutional functions. Firstly, parliamentary governments ought to be able to win a vote of confidence. This type of vote can come in different forms according to their 
Table 1. Governments (Cabinets) in Poland 1989-2007

\begin{tabular}{|c|c|c|c|c|c|c|}
\hline No. & $\begin{array}{l}\text { Prime } \\
\text { Minister }\end{array}$ & $\begin{array}{l}\text { Political Parties Respon- } \\
\text { sible for Forming and } \\
\text { Ruling the Cabinet }\end{array}$ & $\begin{array}{l}\text { Period of } \\
\text { Activeness }\end{array}$ & $\begin{array}{l}\text { Durability } \\
\text { of Cabinet } \\
\text { in Months } \\
\text { (Days) }\end{array}$ & $\begin{array}{l}\text { Type of } \\
\text { Cabinet }\end{array}$ & $\begin{array}{l}\text { Time of } \\
\text { Establi- } \\
\text { shing the } \\
\text { Cabinet }\end{array}$ \\
\hline 1 & $\begin{array}{l}\text { Tadeusz } \\
\text { Mazowiecki }\end{array}$ & $\begin{array}{l}\text { at the beginning: PZPR, ZSL, } \\
\text { SD; at the end: UD, PSL, SD, } \\
\text { ROAD, FPD }\end{array}$ & $\begin{array}{l}\text { 12.09.1989- } \\
04.01 .1991\end{array}$ & $16(430)$ & $\begin{array}{l}\text { Cross-party } \\
\text { Coalition }\end{array}$ & - \\
\hline 2 & $\begin{array}{l}\text { Jan Krzysztof } \\
\text { Bielecki }\end{array}$ & KLD, PC, ZChN, SD & $\begin{array}{l}04.01 .1991- \\
06.12 .1991\end{array}$ & $11(330)$ & $\begin{array}{l}\text { Cross-party } \\
\text { Coalition }\end{array}$ & 10 \\
\hline 3 & Jan Olszewski & PC, ZChN, PL, NSZZ „S” & $\begin{array}{l}\mathbf{0 6 . 1 2 . 1 9 9 1 -} \\
05.06 .1992\end{array}$ & $6(180)$ & $\begin{array}{l}\text { Minority } \\
\text { Coalition }\end{array}$ & 17 \\
\hline 4 & $\begin{array}{l}\text { Hanna } \\
\text { Suchocka }\end{array}$ & $\begin{array}{l}\text { UD, ZChN, KLD, PL, PCD, } \\
\text { SLCh, PPG }\end{array}$ & $\begin{array}{l}10.07 .1992- \\
25.05 .1993\end{array}$ & $10,5(315)$ & $\begin{array}{l}\text { Minority } \\
\text { Coalition }\end{array}$ & 10 \\
\hline 5 & $\begin{array}{l}\text { Waldemar } \\
\text { Pawlak }\end{array}$ & SLD, PSL & $\begin{array}{l}\text { 26.10.1993- } \\
07.03 .1995\end{array}$ & $16(480)$ & $\begin{array}{l}\text { Majority } \\
\text { Coalition }\end{array}$ & 16 \\
\hline 6 & Józef Oleksy & SLD, PSL & $\begin{array}{l}07.03 .1995- \\
07.02 .1996\end{array}$ & $11(330)$ & $\begin{array}{l}\text { Majority } \\
\text { Coalition }\end{array}$ & 5 \\
\hline 7 & $\begin{array}{l}\text { Włodzimierz } \\
\text { Cimoszewicz }\end{array}$ & SLD, PSL & $\begin{array}{l}07.02 .1996- \\
31.10 .1997\end{array}$ & $21(630)$ & $\begin{array}{l}\text { Majority } \\
\text { Coalition }\end{array}$ & 6 \\
\hline 8 & Jerzy Buzek & AWS, UW & $\begin{array}{l}\text { 31.10.1997- } \\
07.06 .2000\end{array}$ & $31(930)$ & $\begin{array}{l}\text { Majority } \\
\text { Coalition }\end{array}$ & 26 \\
\hline 9 & Jerzy Buzek & AWS & $\begin{array}{l}07.06 .2000- \\
19.10 .2001\end{array}$ & $16,5(495)$ & $\begin{array}{l}\text { Single-party } \\
\text { Minority }\end{array}$ & - \\
\hline 10 & Leszek Miller & SLD-UP, PSL & $\begin{array}{l}\text { 19.10.2001- } \\
04.03 .2003\end{array}$ & $16,5(495)$ & $\begin{array}{l}\text { Majority } \\
\text { Coalition }\end{array}$ & 8 \\
\hline 11 & Leszek Miller & SLD & $\begin{array}{l}04.03 .2003- \\
02.05 .2004 \\
\end{array}$ & $14(420)$ & $\begin{array}{l}\text { Single-party } \\
\text { Minority }\end{array}$ & - \\
\hline 12 & Marek Belka & SLD & $\begin{array}{l}02.05 .2004- \\
31.10 .2005\end{array}$ & $18(540)$ & $\begin{array}{l}\text { Single-party } \\
\text { Minority }\end{array}$ & 53 \\
\hline 13 & $\begin{array}{l}\text { Kazimierz } \\
\text { Marcinkiewicz }\end{array}$ & PiS & $\begin{array}{l}\text { 31.10.2005- } \\
27.04 .2006\end{array}$ & $5,5(165)$ & $\begin{array}{l}\text { Single-party } \\
\text { Minority }\end{array}$ & 11 \\
\hline 14 & $\begin{array}{l}\text { Kazimierz } \\
\text { Marcinkiewicz }\end{array}$ & PiS, LPR, SRP & $\begin{array}{l}27.04 .2006- \\
14.07 .2006\end{array}$ & $3(90)$ & $\begin{array}{l}\text { Majority } \\
\text { Coalition }\end{array}$ & - \\
\hline 15 & $\begin{array}{l}\text { Jarosław } \\
\text { Kaczyński }\end{array}$ & PiS, LPR, SRP & $\begin{array}{l}14.07 .2006- \\
21.09 .2006\end{array}$ & $2(60)$ & $\begin{array}{l}\text { Majority } \\
\text { Coalition }\end{array}$ & 6 \\
\hline 16 & $\begin{array}{l}\text { Jarosław } \\
\text { Kaczyński }\end{array}$ & PiS, LPR & $\begin{array}{l}21.09 .2006- \\
15.10 .2006\end{array}$ & $1(30)$ & $\begin{array}{l}\text { Minority } \\
\text { Coalition }\end{array}$ & - \\
\hline 17 & $\begin{array}{l}\text { Jarosław } \\
\text { Kaczyński }\end{array}$ & PiS, LPR, SRP & $\begin{array}{l}15.10 .2006- \\
11.08 .2007\end{array}$ & $9,5(285)$ & $\begin{array}{l}\text { Majority } \\
\text { Coalition }\end{array}$ & - \\
\hline 18 & $\begin{array}{l}\text { Jarosław } \\
\text { Kaczyński }\end{array}$ & PiS & $\begin{array}{l}11.08 .2007- \\
16.11 .2007\end{array}$ & $4,5(135)$ & $\begin{array}{l}\text { Single-party } \\
\text { Minority }\end{array}$ & - \\
\hline
\end{tabular}

Source: own study based on information from official sites (www.premier.gov.pl, www.sejm.gov.pl). Party names: AWS = Electoral Action Solidarity of the Right; KLD = Liberal Democratic Congress; LPR $=$ League of Polish Families; PC = Centre Alliance; PCD = Party of Christian Democrats; PiS = Law and Justice; PL = Peasant Alliance; $\mathrm{PO}=$ Civic Platform; $\mathrm{PPG}=$ Polish Economic Programme; PSL = Polish Peasant Party; SLD = Democratic Left Alliance; SDPL = Polish Social Democracy; SRP = Self-defence of the Republic of Poland; UD = Democratic Union; UP = Union of Labour; UW = Freedom Union; WAK = Catholic Election Action; NSZZ "S" = Trade Union Solidarity, SD = Democratic Party; ZSL = United Peasants Party; ZChN = Christian National Unity; PZPR = Polish United Workers Party 
origins. Vote of confidence may be demanded by the government itself (usually any time the government requests it) or it may be required by the constitutional regulation (particularly at the time when a new government first presents itself to the legislature). This necessity of winning vote of confidence is very often called by experts a viability requirement, because if such voting ends negatively, the government simply vanishes (Strøm, 1990, p. 5).

Secondly, constitutional functions of government are also very often connected with effectiveness, so it is obvious the governments must be both viable and effective. Such conditions are fulfilled by legislative coalitions which consist of the political parties from which the members of the governments are drawn. In coalition-theoretic parlance, the assumption are that the coalitions over policy and office are identical and that they can be identified as the parties holding cabinet portfolios.

The term government (cabinet) in Poland is most frequently understood as executive body enjoying the trust of the legislature, which in the basic law is simply called the Council of Ministers. An additional condition clarifying such a government is its specific political configuration, in other words, a single party or party coalition that manages the most important executive offices - the position of the Prime Minister and ministers. In consequence we should remember that if there is a change in the Prime Minister position or a political configuration is being transformed by changing the coalition (e.g., leaving or joining a new party) - we then have a completely new cabinet. Such argumentation, although very popular among political scientists and lawyers, is not the only one and one can also find a different thesis, according to which the criterion of changing the cabinet is associated only with a change in the position of the Prime Minister. For the purposes of this study, however, the most-chosen version was adopted by the constitutional experts, that one Prime Minister may lead several cabinets with different party compositions, and within the same political base several cabinets may function when the change takes place only in the Prime Minister position (Radek, 2009, p. 208).

As it was mentioned above, minority government (cabinet) is most often characterized by experts as a cabinet formed in a parliamentary system when a political party or coalition of parties does not have a majority of overall seats in the parliament. It is sworn into office, with or without the formal support of other parties, to enable a government to be formed. Under such a government, legislation can only be passed with the support of enough other members of the legislature to provide a majority, encouraging multi-partisanship. However, 
majority or minority governments do not altogether exhaust the set of possible cabinet solutions. A further possibility is non-partisan solution, such as a caretaker or business administration. It also must be stressed that governing capacity is defined as the government's ability to make significant, authoritative decisions regarding the country's public policies. In that case, a legislative success most intuitively taps into the definition of governing capacity because it directly measures decision-making on public policies that must pass through parliament (Field, 2016, p. 78).

It should be remembered that many minority and some majority governments are precisely caretaker governments, however such distinguishing characteristic is not as important as nonpartisanship position of such cabinet. In the literature, many authors very often concentrate on single-party and coalition governments, and claim that they form under distinct conditions: single-party government in majority situations, when one party controls a majority of the legislature, and coalition government in minority situations, when no party is in power to control a majority of the legislature.

In parliamentary democracies both minority and nonpartisan governments are treated as a kind of deviation. Nonpartisan governments violate the most fundamental norm, that of party government (Sartori, 1976; Rose, 1974). Minority governments violate the expectation that executive and legislative coalitions are the same coalitions and it is extremely difficult to say what would cause such distinction between them. Why would any party agree to support the government legislatively if it gets no portfolios in exchange? Also quite interesting scientifically is finding the answer to the question why the opposition, by definition a majority coalition in parliament in that case, does not create the government and take the spoils of office for itself. These facts indicate that minority government is a counterintuitive phenomenon in the world of parliamentary democracies, where the expectation of majority government is conventionally understood as an axiom. Any occurrence of minority government therefore seems to threaten the entire edifice of deductive coalition theory. Given the counterintuitive nature of minority governments, the question is whether they can be as easily dismissed as nonpartisan administration (Strøm, 1990, p. 8). 


\section{GOVERNMENT PERFORMANCE IN POLAND}

This section provides an assessment of the performance of minority governments in Poland between 1989 and 2007. It employs two standard indicators of government performance: government duration and legislative success. There could be also analysed, as Strøm (1990) stresses, third important indicator, which is governing party's electoral performance in the subsequent election, but this element may broaden and extend the article too much, so the author resigns to unpack it. Two mentioned above indicators demonstrate that Polish minority governments outperform minority governments cross-nationally and that while Polish majority governments performed slightly better than minority ones between 1989 and 2007, as operationalised here, the differences are not great. If we eliminate first two governments of Tadeusz Mazowiecki and Jan Krzysztof Bielecki, there is little difference between minority and majority government performance. There are also good theoretical reasons to only consider the post-1991 period (this election was the first one fully democratic and free). Most experts claim that Polish democracy was not consolidated until 1997, and some of the crucial institutional arrangements were developed in the 1997 Constitution of the Republic of Poland. In fact, the establishment of new Polish Constitution and changes in the party system helped to stabilise governments which has been protected by the normative regulations.

Using a definition of government termination that includes changes in the partisan composition of the cabinet, the Prime Minister, coalition status, or new elections (Lijphart, 1999), the average duration of all Polish governments form 1989 till 2007 is not very long - 355 days or almost one year (see: Table 1). This does not exceed the cross-national average cabinet duration of 2.12 years found in Lijphart's study (1999, p. 137) of 36 democracies and is over two times lower. The average duration of Polish majority governments is 1,13 years (411 days) compared with 0,78 years (285 days) for minority ones. However, between 1989 and 2007, the distance in duration of minority and majority governments in Poland was 0,35 years (126 days), which is roughly half of the minority governments durability time at all. Both statistics for cross-national average of 1.64 years for single-party minority governments in Lijphart's research far exceed Polish minority governments (Lijphart, 1999, p. 137). Polish minority governments last far shorter than their Western counterparts (average of 601 days) (Gallagher, Laver, \& Mair, 2006, p. 410). They also do not appear to have more difficulty in the formation process (see: Table 1). On average, government formation for all types 
takes in Poland only 9,33 days. There must be stressed a really small difference between the time necessary to establish minority and majority governments. On the one hand, majority governments are obviously formed faster and easier and this process lasts 7,7 days. On the contrary, the minority ones are formed longer, i.e., 11,38 days, which is also not a symbol of crisis. It is even possible to claim that in Poland the minority or majority status of the government does not influence the time of establishing the government. In my opinion, this is probably caused by the underdeveloped party system in Poland and not the real political base in the parliament.

One of the main reasons that influenced the duration of minority governments in the analysed period 1989-2007 was the situation on the party scene and individual parliamentary members' fears of earlier elections. It is worth noticing that parliament's terms of office was shortened only once by the will of the parliamentary members, which happened in 2007. The decision was then enforced by the leader of Law and Justice - Jarosław Kaczyński. His strategy was obvious, i.e., he wanted to avoid the uncomfortable situation for the government attacked by the opposition. However, after earlier election in 2007, the control of government was lost by Law and Justice, but still, in the long run, Jarosław Kaczyński avoided weak electoral results and was able to control the party scene in Poland.

The second performance indicator is the legislative success of the governments, measured by the percentage of government bills presented that are approved. Overall, Polish governments perform quite well in this sphere (see: Tables 2 and 3).

The participation of the government in legislative proceedings has not only a practical dimension that influences the effectiveness of governance, but is also important from the point of view of the principle of legalism and other components of the democratic state ruled by law. In a state that wants to be treated not only seriously, but also perceived as adhering to the rule of law, a political program can only be implemented through laws, especially where there is no government delegated legislation. In accordance with the imperative of cooperation of the legislature and the executive in this system, the act should be a joint work of the government and parliament, in this way that the government prepares projects, while the parliament adopts them, thus enabling the government's key functions of ruling. In addition, the legislative aspect at the level of the European Union is an additional factor raising the rank of the legislative role of the government, 
which is reflected in the construction of the EU decision-making process. The most characteristic feature of the EU legislative process is the conversion of the systemic roles of the legislature and the executive versus the classical division of power. This executive actually creates EU law with the participation of the parliament, and the member states' parliaments possibly carry them out, when it takes the form of directives and controlling government representatives in the EU decision-making structures, while controlling the legislative process is in the interest of the national sovereign (Patyra, 2011, p. 122).

Currently, the existing constitutional solutions in Poland dedicate only a few normative instruments through which the Council of Ministers is able to influence the legislative process. These instruments include, first of all, the right of legislative initiative, which is widely recognized as an irreducible principle in the parliamentary-cabinet system, and the experience of Polish constitutionalism so far indicates that the government has always been an entity equipped with this right. Past experience shows also that the Council of Ministers is the most active entity among five equipped by the Constitution in this law. All bills submitted by the government are subject to specific formal requirements, including the obligation to consult, the obligation to draw up socio-economic effects related to the entry into force of the act, and the drafting of implementing acts (Mistygacz, 2012b, pp. 117-118).

In the case of the government, it must be stressed that the President, as the second part of the executive branch, is extremely important. The personal right of the head of state in the field of legislative initiative may in fact destabilize and conflict the dual executive, which unfortunately, may affect the quality of governance. Leaving aside the intentions of both the government and the President himself, it may occur that both sides will compete with each other and even deliberately interfere with the achievement of political goals. It can generate two extremely interesting situations. The first of these is the cohabitation situation, and the second is the emergence of a minority cabinet. In both cases, and especially in the second one, presidential role in the political system and its impact on the legislative process can significantly increase. It is believed that some political elites in the destabilized parliament will strive to satisfy the alternative political centre, pursuing their particular interests.

As Table 2 shows, the dominance of the government over the President in the field of initiating legal acts is enormous and confirms the existence of a parliamentary-cabinet system in Poland. The role of the President is marginal here, which is indeed not surprising. 
Table 2. Number of Bills Submitted in the Parliament (Lower Chamber)

\begin{tabular}{|l|c|c|c|}
\hline \multirow{2}{*}{ Term of Office } & \multicolumn{3}{|c|}{ Number of submitted bills (legislative initiative) } \\
\cline { 2 - 4 } & Council of Ministers & President & $\begin{array}{c}\text { Government projects among executive } \\
\text { projects in per cent (\%) }\end{array}$ \\
\hline X (1989-1991) & 144 & 6 & 96 \\
\hline I (1991-1993) & 80 & 5 & 94,1 \\
\hline II (1993-1997) & 334 & 15 & 95,9 \\
\hline III (1997-2001) & 553 & 16 & 97,2 \\
\hline IV (2001-2005) & 808 & 21 & 97,5 \\
\hline V (2005-2007) & 377 & 23 & 94,3 \\
\hline Average & $\mathbf{3 8 3}$ & $\mathbf{1 4}$ & $\mathbf{9 5 , 8}$ \\
\hline
\end{tabular}

Source: own study based on information from official site - www.sejm.gov.pl, and Mistygacz, 2012a, p. 285.

The issue of legislative effectiveness of minority governments seems to be more interesting. In order to find and confirm the links between legislative effectiveness and the functioning of minority cabinets, it is first necessary to provide aggregated data on this topic, presented in Table 3 . The reader will also find there some data presenting the legislative effectiveness of other entities entitled to submit bills in the Polish parliament. The list of entities itself illustrates the dominance of government projects.

Table 3. Legislative Effectiveness of the Government in the Light of the Effectiveness of Other Entities

\begin{tabular}{|l|c|c|c|c|c|c|c|}
\hline \multirow{2}{*}{ Term of Office } & \multicolumn{7}{|c|}{ Legislative Effectiveness in per cent \% } \\
\cline { 2 - 8 } & $\begin{array}{c}\text { Council of } \\
\text { Ministers }\end{array}$ & $\begin{array}{c}\text { Parlia- } \\
\text { mentary } \\
\text { Members }\end{array}$ & $\begin{array}{c}\text { Sejm's } \\
\text { Committees }\end{array}$ & Senate & President & Citizens & Average \\
\hline X (1989-1991) & 60 & 55 & 52 & 58 & 50 & 48 & 53,83 \\
\hline I (1991-1993) & 55 & 24 & 31 & 20 & 20 & 15 & 28 \\
\hline II (1993-1997) & 92 & 42 & 70 & 60 & 33 & 55 & 58,67 \\
\hline III (1997-2001) & 81 & 41 & 78 & 41 & 31 & 40 & 52 \\
\hline IV (2001-2005) & 91 & 51 & 82 & 64 & 71 & 38 & 66,17 \\
\hline V (2005-2007) & 77 & 44 & 27 & 19 & 74 & 12 & 42,17 \\
\hline Average & 76 & 42,83 & 56,67 & 43,67 & 46,67 & 34,67 & - \\
\hline
\end{tabular}

Source: own study based on information from official site - www.sejm.gov.pl, and Mistygacz, 2012a, pp. 292-294; Dudzińska, 2015, p. 71. 
According to the Table 1 and Table 3, we can see a correlation that in the terms of parliaments I, III, IV and V, in which there were minority governments, the effectiveness of government legislation was smaller than in the second term in which the coalition majority government operated. Although in the fourth term of office, the success rate in adopting governmental projects was at a decent high level despite the existence of the government without the support of the majority, however, this condition was caused by the specific political situation strongly connected with the process of Poland's accession to the European Union. During this period, legislative work aimed at adapting Polish law to the EU's was intensified and the government as the participant of the process led the way in creating proposals and modifying normative solutions. It was a natural situation because governments are usually best-informed and substantively prepared in these matters. It should also be noted that in the period when only minority governments dominated (parliamentary terms 1991-1993 and 2005-2007), legislative effectiveness was definitely lower. The parliamentary term from 1997 till 2001 was not only the time of preparations for Poland's accession to the European Union but also numerous reforms of the political system, when the Prime Minister was Jerzy Buzek.

It should also be noted that minority governments were not able to pushthrough any significant bills and the thesis about the administrative nature of such offices without a strategic vision of governance was confirmed. In the periods when the minority government was dominating in the executive, no major laws or projects were noted, so logically the existing solutions were not fundamentally remodelled. There was also a visible situation that number of projects approved by the cabinets were decreased especially at this time and in consequence there was a drop of average result for the whole parliament. One of the reasons for this situation was also the failure of the minority government to take such initiatives, which are often controversial in assumptions and for their success there is necessary the majority in the lower chamber of the parliament (Sejm). There is no impact of normative solution here, which is the same as in the case of a government with a majority or only a minority background. 


\section{CONCLUSIONS}

In conclusion, based on the Polish experience, it is possible to confirm the hypothesis assumed in the introduction that the functioning of minority offices is not conducive to the legislative effectiveness of governments without a solid support in the parliament. In Poland, majority governments are a little bit more successful legislatively than minority ones. However, there was no big difference between majority and minority governments between 1989-2007 in durability and time necessary to establish a new cabinet. Not only the lack of the majority to pass laws, but also other internal factors may ultimately lead to the fall of the government and the shortening of the term of office, which results in the principle of discontinuation of parliamentary work. A separate issue requires further research to find an answer to the following question: who is the real author of realised projects? Finding an answer to the mentioned question is not an easy task.

In Poland, minority governments are also not legislatively less productive, as measured by the number of government-initiated laws passed. The difference largely occurs if we underline the accession to the European Union, which caused a higher number of laws, because parliament was engaged in building a new legal standardised system in Poland.

To sum up, Polish minority governments perform as well as single-party and coalition majority governments in the post-1989 period. Even if we include the 1989-1991 (not fully democratic parliament) data, minority governments do not significantly underperform compared with majority ones in Poland.

\section{REFERENCES:}

Dudzińska, A. (2015). System zamknięty. Socjologiczna analiza procesu legislacyjnego. Warszawa: Wydawnictwo Naukowe SCHOLAR.

Field, B.N. (2014). Minority Parliamentary Government and Multilevel Politics: Spain's System of Mutual Back Scratching. Comparative Politics, 46(3), 293-312.

Field, B.N. (2016). Why Minority Governments Work: Multilevel Territorial Politics in Spain. New York: Palgrave Macmillan.

Gallagher, M., Laver, M., \& Mair, P. (2006). Representative Government in Modern Europe. Boston: McGraw Hill.

Lijphart, A. (1999). Patterns of Democracy: Government Forms and Performance in Thirty-Six Countries. New Haven and London: Yale University Press. 
Mistygacz, M. (2012a). Rola rządu w procesie ustawodawczym (w systemie parlamentarnym). In: T. Mołdawa, J. Szymanek, \& M. Mistygacz (eds.). Parlamentarny system rząów. Teoria i praktyka (pp. 282-295). Warszawa: Dom Wydawniczy Elipsa.

Mistygacz, M. (2012b). Rzad w procesie ustawodawczym w Polsce. Warszawa: Dom Wydawniczy Elipsa.

Patyra, S. (2011). Wpływ Rady Ministrów na proces ustawodawczy w kontekście racjonalizacji systemu rządów. In: B. Paździor, \& M. Szmulik (eds.). Wybrane aspekty parlamentaryzmu zracjonalizowanego (pp. 117-139). Lublin: Wyższa Szkoła Ekonomii i Innowacji w Lublinie.

Radek, R. (2009). Rola i pozycja Rady Ministrów w okresie transformacji ustrojowej w Polsce - model konstytucyjny i praktyka polityczna. In: R. Glajcar, \& W. Wojtasik (eds.). Transformacja systemowa w Polsce 1989-2009. Próba bilansu (pp. 207-227). Katowice: Instytut Nauk Politycznych i Dziennikarstwa Uniwersytetu Śląskiego.

Rose, R. (1974). The Problem of Party Government. London: Palgrave Macmillan.

Sartori, G. (1976). Parties and Party Systems: A Framework for Analysis. Cambridge: Cambridge University Press.

Strøm, K. (1990). Minority Government and Majority Rule. Cambridge: Cambridge University Press.

Strona internetowa Premiera (2019). Retrieved from: www.premier.gov.pl.

Strona internetowa Sejmu (2019). Retrieved from: www.sejm.gov.pl. 